\title{
Impact of educational lectures on female adolescents' knowledge about sexually transmitted diseases and cervical cancer in the city of Jundiaí, SP
}

\author{
Impacto das palestras educativas no conhecimento das adolescentes em relação às doenças \\ sexualmente transmissíveis e câncer do colo uterino em Jundiaí, SP
}

\author{
João Bosco Ramos Borges ${ }^{1}$, Marcus Vinícus Gonçalves Belintani², Patrícia Frodl Miranda², \\ Ana Carolina Marchesini de Camargo ${ }^{4}$, Renata Guarisi ${ }^{5}$, Edna Marina Cappi Maia ${ }^{6}$, Thomaz Rafael Gollop ${ }^{7}$
}

\begin{abstract}
Objective: To evaluate the knowledge of adolescents living in Vila Ana and Morada das Vinhas region, in the city of Jundiaí, State of São Paulo, Brazil, on prevention and diagnosis of the main sexually transmitted diseases (STDs) and on cervical cancer, as well as the immediate impact of educational lectures. Methods: A prospective cross-sectional study was performed to assess the knowledge of a particular group of female adolescents about STDs and cervical cancer, by means of a questionnaire applied before and after educational lectures. Results: After the lecture, there was an increased number of correct answers about sexual education, knowledge about HPV (44\%), and prevention of cervical cancer (22\%). Conclusion: The adolescents in our study had little knowledge about STDs and cervical cancer, but educative lectures could change this reality at a low cost to Public Health services.
\end{abstract}

Keywords: Knowledge; Sexually transmitted diseases; Uterine cervical neoplasms; Sex education

\section{RESUMO}

Objetivo: Avaliar o conhecimento das adolescentes moradoras nas regiões abrangentes da Vila Ana e da Morada das Vinhas, na cidade de Jundiaí (SP), sobre a prevenção e diagnóstico das principais doenças sexualmente transmissíveis (DSTs) e do câncer de colo do útero, além de avaliar o impacto imediato de palestras educativas. Métodos:
Foi realizado estudo prospectivo de corte transversal para avaliar 0 conhecimento de um determinado grupo de adolescentes sobre DSTs e câncer do colo uterino, por meio de um questionário aplicado antes e logo após a realização de palestra educativa. Resultados: Após a exposição da palestra, houve aumento de respostas corretas sobre educação sexual, conhecimento do HPV (em 44\%) e sobre a prevenção do câncer de colo de útero (em 22\%). Conclusão: As adolescentes que participaram do estudo têm pouco conhecimento em relação às DSTs e câncer do colo uterino, mas as palestras educativas são capazes de reverter essa realidade com baixo custo à Saúde Pública.

Descritores: Conhecimento; Doenças sexualmente transmissíveis; Neoplasias do colo do útero; Educação sexual

\section{INTRODUCTION}

Sexuality is present throughout the life of humans, and seek its confirmation during adolescence ${ }^{(1)}$. Notwithstanding, sexuality development is not always followed by affective and cognitive maturing, which makes adolescence a highly vulnerable stage for humans, with some risks, such as undesired pregnancy and sexually transmitted diseases (STDs) ${ }^{(1)}$. The majority of women start sexual activities during adolescence, at an increasingly younger

\footnotetext{
Study carried out at the Discipline of Gynecology of the Department of Gynecology and Obstetrics of Faculdade de Medicina de Jundiaí - FMJ, Jundiai (SP), Brazil.

${ }^{1}$ Full Professor of Gynecology of Faculdade de Medicina de Jundiaí - FMU, Jundiaí (SP), Brazil.

${ }^{2}$ Medical student of Faculdade de Medicina de Jundiaí - FMJ, Jundiaí (SP), Brazil.

${ }^{3}$ Medical student of Faculdade de Medicina de Jundiaí - FMJ, Jundiaí (SP), Brazil.

${ }^{4}$ Master's degree in Gynecology; Assistant Professor of Gynecology at Faculdade de Medicina de Jundiaí - FMJ, Jundiaí (SP), Brazil.

${ }^{5} \mathrm{PhD}$ in Gynecology from Universidade Estadual de Campinas - UNICAMP, Campinas (SP), Brazil.

${ }^{6} \mathrm{PhD}$; Adjunct Professor of Gynecology at Faculdade de Medicina de Jundiaí - FMJ, Jundiaí (SP), Brazil.

${ }^{7}$ Postdoctorate degree; Associate Professor of Gynecology at Faculdade de Medicina de Jundiaí - FMJ, Jundiaí (SP), Brazil.

Corresponding author: João Bosco Ramos Borges - Rua Francisco Telles, 250 - Vila Arens - CEP 13202-550 - Jundiaí (SP), Brazil - Tel.: (11) 4587-1095 -E-mail: drbosco@terra.com.br

Received on: Oct 06, 2009 - Accepted on: Apr 12, 2010

Project to Foster Scientific Formation Grants - PIBIC/CNPq.

There is no conflict of interest in setting this Project.
} 
age $^{(1)}$, which leads to higher incidence of STDs among teenagers ${ }^{(2,3)}$. The immediate consequences are, for example, urethritis, salpingitis and, in the long run, infertility, ectopic pregnancy and uterine cervical cancer, as well as psychosocial and financial complications ${ }^{(4)}$. We know that STDs are among the five main reasons for people to seek Healthcare services ${ }^{(5)}$.

The World Health Organization (WHO) estimates that there are about 340 million cases of STDs per year, worldwide. This estimate does not include genital herpes and human papilloma virus (HPV) ${ }^{(6)}$. In Brazil, the estimates of sexually transmitted infections in the sexually active population are of 937,000 cases of syphilis; $1,541,800$ cases of gonorrhea; $1,967,200$ cases of chlamydia; 640,900 cases of genital herpes and 685,400 cases of $\mathrm{HPV}^{(6)}$. Nonetheless, it is believed that the number of reported cases is way below estimates ${ }^{(7)}$, maybe because acquired immunodeficiency syndrome (Aids) and syphilis are of compulsory notification and many persons with STDs seek treatment in drugstores instead of looking for medical-hospital care. Moreover, many STDs are asymptomatic, especially among women ${ }^{(8)}$.

Many are the reasons adolescents have for doing unprotected sex. One of them is lack of information, since adolescents seem to not be aware of their own fertile period or use contraceptive pills in a wrong way; or they simply do not believe in the risk of pregnancy or diseases in their first sexual intercourse, considering themselves indestructible and untouchables in their own fantasy thinking ${ }^{(9)}$. Other reasons for not using contraceptive methods are: forgetfulness, cost, and reports of impairing pleasure in the sexual intercourse ${ }^{(9)}$. There is a wide gap between the level of knowledge and the effective use of these methods ${ }^{(1,10)}$. The fact is that one cannot expect adolescents themselves to take on STDs prevention as part of their lives if that does not make sense to them or if they are precluded from using proper methods ${ }^{(11)}$.

In order to stimulate prevention among adolescents concerning STDs, education is fundamental ${ }^{(12)}$. Nonetheless, the educational process is rather complex and involves numerous aspects inherent to the communicator, the communication and the audience so as to make the goals feasible and have them reach the expected targets, when it is not enough to simply provide information - given that "to be informed does not necessarily mean to know; to be aware does not necessarily mean to take measures; and to decide for taking measures does not necessarily mean to do" ${ }^{(12)}$. Therefore, it is necessary to develop the sense of individual and group responsibility; only such commitment can lead to the more effective and accepted behavioral changes, since it is based on acceptance and not on obligation ${ }^{(12)}$.
HPV is a virus of preferable sexual transmission, with high incidences of morbidity and mortality. It is considered an essential etiological agent for the development of cervical cancer - the second most common type of cancer among women, with estimates of 500 thousand new cases and 230 thousand deaths in the entire world, in $2008^{(13)}$. Its incidence in developing countries is about twice as high when compared to more developed countries; and the prevalence of cervix cancer becomes evident in the age range of 20 to 29 years and the risk increases quickly until its peak is reached in the age range between 45 and 49 years $^{(13)}$. It is a neoplasia also associated to extrinsic factors, that is, factors associated with the environment and lifestyle; nonetheless, it is not easy to change the lifestyle of a population, especially amidst poverty and deficient education ${ }^{(14-16)}$.

According to the Datasus, the total number of HPVinduced neoplasias in the State of São Paulo, Brazil, from January to July of 2006, was 3,455, being more concentrated in age ranges when women have a more active sexual life (from 15 to 39 years of age). In the city of Jundiaí, São Paulo, Brazil, in the same period, 737 cases of cervical squamous metaplasia were diagnosed, amongst which 58 cases were associated with HPV infection ${ }^{(7)}$. Also in Jundiaí, this infection reaches earlier ages, reinforcing the importance of an approach with adolescents in the city so that prevention can be more efficient ${ }^{(8)}$.

The Brazilian program for early detection and diagnosis of lesions which are precursors of cervical cancer (secondary prevention) is based on periodical Pap smear test. The target population is sexually active women, especially those in the age range of 25 to 59 years $^{(9)}$.

Some studies carried out in South America confirm the lack of information and the low level of knowledge about STDs, and warn to the lack of proper sexual education ${ }^{(17)}$.

\section{OBJECTIVE}

To assess the knowledge of female adolescents living in the regions of Vila Ana and Morada das Vinhas, in the city of Jundiaí, São Paulo, Brazil, on the prevention and diagnosis of the main STDs and cervical cancer, as well as to assess the immediate impact of educational talks.

\section{METHODS}

A prospective, cross-section study was carried out in public schools: Escola de Ensino (EE) Cel. Siqueira de Moraes, which serves the dwellers of Vila Ana and the schools: Escola Municipal de Ensino Básico (EMEB) Prof. Albino Melo de Oliveira, EMEB Morada das Vinhas and EE Padre Maurílio Tomanik, which serve the dwellers of the Morada das Vinhas district. This study was approved by the Research Ethics Committee of the Faculdade 
de Medicina de Jundiaí. The knowledge of female adolescents $\left(6^{\text {th }}\right.$ to $9^{\text {th }}$ grades of the primary education/ junior school) was assessed by means of a questionnaire (Appendix 1), applied before and immediately after the educational lecture, given in a classroom of the school, on the topic: "Prevention and diagnosis of cervical cancer and STD transmission". Immediately before the lecture, an oral informed consent form was read.

After being answered by the adolescents, the questionnaires were revised and filed, and later a database was made using the Excel software (Microsoft ${ }^{\circledR}$ ). For statistical analysis purposes we used the SAS 9.02 software (SAS Institute Inc., Cary, NC, USA) and the $\chi^{2}$ tests (McNemar and Pearson), Odds Ratio and Fisher's exact test.

\section{RESULTS}

A total of 164 female students were submitted to the questionnaire. Their ages varied between 12 and 17 years (Figure 1), of which $42.3 \%$ were in the 7 th grade and $57.7 \%$ the 8 th grade.

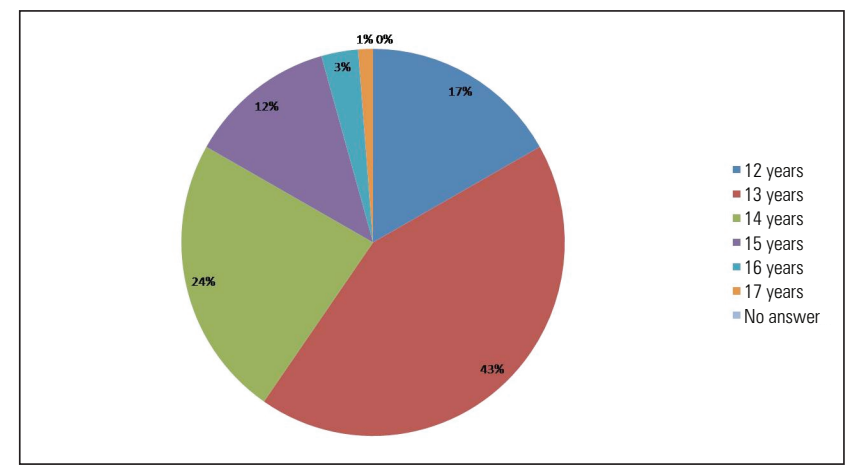

Figure 1. Age of the participants of the survey

Before the educational lecture, AIDS was the STD best known by the students, remembered by $86.6 \%$ of the interviewees; followed by syphilis $(12.8 \%)$ and gonorrhea (11.6\%). After the lecture, AIDS was mentioned in $97 \%$ of questionnaires, HPV in $75 \%$, gonorrhea in $34.1 \%$ and syphilis in $34.1 \%$ (Figure 2).

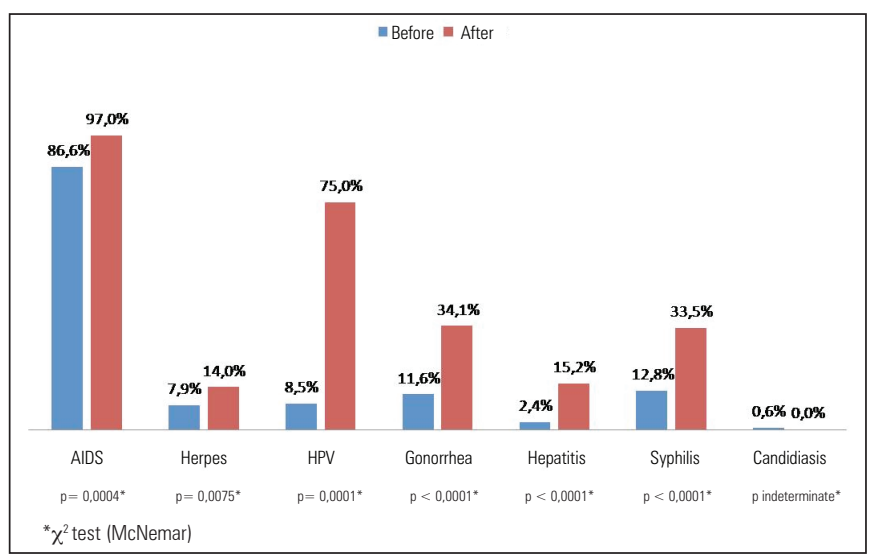

Figure 2. Sexually transmitted diseases most often cited during the study
As far as HPV is concerned, before the lecture, only $3 \%$ knew exactly what it meant; and after it, the number rose to $47.6 \%$. Only $79.3 \%$ had already heard of Pap smear, and most of them (30.8\%) obtained such information at home. After the lecture, $91.5 \%$ of the students answered yes, $36 \%$ reported having heard about it at school and $21.3 \%$ heard about it in talks. Nonetheless, $42.7 \%$ did not know why Pap smear was done and only $64.6 \%$ deemed it very important to do it. After the lecture, $59.1 \%$ stated that such test could prevent cervical cancer, and $88.4 \%$ stated to consider it very important to undergo the test (Table 1 ). As to the importance of using condoms, $88.4 \%$ answered it was very important to use them and, after the lecture, $90.9 \%$ of interviewees considered important to use condoms.

Table 1. Knowledge of female adolescents participating in the study on HPV and Pap smear test

\begin{tabular}{|c|c|c|c|c|c|}
\hline \multirow{2}{*}{ Questions } & \multicolumn{2}{|c|}{ Before } & \multicolumn{2}{|c|}{ After } & \multirow{2}{*}{$\mathrm{p}$ value } \\
\hline & $\mathbf{n}$ & $\%$ & $\mathbf{n}$ & $\%$ & \\
\hline Have you heard about HPV? & & & & & $0.1107^{*}$ \\
\hline I have never heard & 59 & 36.0 & 7 & 4.3 & \\
\hline $\begin{array}{l}\text { I have heard, but I do not know exactly } \\
\text { what it is }\end{array}$ & 97 & 59.1 & 73 & 44. & \\
\hline I have heard, and I know what it is & 5 & 3.0 & 78 & 47.6 & \\
\hline No answer & 3 & 1.8 & 6 & 3.7 & \\
\hline Have you heard about Pap smear test? & & & & & 0.0001 \\
\hline I have never heard & 33 & 20.1 & 10 & 6.1 & \\
\hline I have heard & 130 & 79.3 & 150 & 91.5 & \\
\hline No answer & 1 & 0.6 & 4 & 2.4 & \\
\hline \multicolumn{6}{|l|}{ Where have you heard about it? } \\
\hline School & 11 & 8.5 & 54 & 36.0 & $<0.0001$ \\
\hline Television & 11 & 8.5 & 20 & 13.3 & 0.0495 \\
\hline Newspaper & 3 & 2.3 & 9 & 6.0 & 0.0339 \\
\hline Lectures & 9 & 6.9 & 32 & 21.3 & $<0.0001$ \\
\hline At home & 40 & 30.8 & 37 & 24.7 & 0.5775 \\
\hline By friends & 6 & 4.6 & 7 & 4.7 & 0.7630 \\
\hline Other places & 2 & 1.5 & 2 & 1.3 & 10.000 \\
\hline What is the Pap smear test for? & & & & & $0.0070^{*}$ \\
\hline I do not know & 70 & 42.7 & 16 & 9.8 & \\
\hline To avoid diseases & 23 & 14.0 & 18 & 11.0 & \\
\hline To avoid uterine cervical cancer & 38 & 23.2 & 97 & 59.1 & \\
\hline To avoid any cancer in women & 33 & 20.1 & 31 & 18.9 & \\
\hline $\begin{array}{l}\text { Do you think it is necessary to undergo } \\
\text { this test? }\end{array}$ & & & & & $0.0018^{*}$ \\
\hline I do not know & 47 & 28.7 & 7 & 4.3 & \\
\hline I think it is not necessary & 1 & 0.6 & 2 & 1.2 & \\
\hline I think it is not very necessary & 9 & 5.5 & 9 & 5.5 & \\
\hline I think it is very necessary & 106 & 64.6 & 145 & 88.4 & \\
\hline No answer & 0 & 0.0 & 1 & 0.6 & \\
\hline Who should undergo this test? & & & & & $0.0159^{*}$ \\
\hline Women with active sexual life & 99 & 60.4 & 136 & 82.9 & \\
\hline Women after menarche (first menses) & 43 & 26.2 & 21 & 12.8 & \\
\hline Women aged over 5 years & 8 & 4.9 & 4 & 2.4 & \\
\hline I do not know & 3 & 1.8 & 0 & 0.0 & \\
\hline No answer & 11 & 6.7 & 3 & 1.8 & \\
\hline
\end{tabular}

Tests used: $\chi^{2}$ test - McNmear; * Fisher's exact test. 
Among the students who participated, 58.5\% were not aware of a test used to prevent cervical cancer. After the lecture, $80.5 \%$ were aware of such test (Table 2).

Table 2. Knowledge of female adolescents participating in the study on cervical cancer prevention

\begin{tabular}{|c|c|c|c|c|c|}
\hline \multirow{2}{*}{ Questions } & \multicolumn{2}{|c|}{ Before } & \multicolumn{2}{|c|}{ After } & \multirow{2}{*}{ p value } \\
\hline & n & $\%$ & $\mathbf{n}$ & $\%$ & \\
\hline Do you know someone who had cervical cancer? & & & & & 0.8886 \\
\hline I have never heard & 106 & 64.6 & 105 & 64.0 & \\
\hline I have heard & 56 & 34.1 & 53 & 32.3 & \\
\hline No answer & 2 & 1.2 & 6 & 3.7 & \\
\hline \multicolumn{6}{|l|}{ Where have you heard about it?? } \\
\hline School & 1 & 1.8 & 9 & 17.0 & 0.0114 \\
\hline Television & 10 & 17.9 & 6 & 11.3 & 0.1573 \\
\hline Newspaper & 1 & 1.8 & 2 & 3.8 & 0.3173 \\
\hline Lectures & 1 & 1.8 & 4 & 7.5 & 0.1797 \\
\hline At home & 8 & 14.3 & 10 & 18.9 & 0.5930 \\
\hline By friends & 8 & 14.3 & 2 & 3.8 & 0.0578 \\
\hline Other places & 0 & 0.0 & 2 & 3.8 & - \\
\hline $\begin{array}{l}\text { Do you know if there is any test to prevent } \\
\text { cervical cancer? }\end{array}$ & & & & & $0.0098^{*}$ \\
\hline I do not know & 96 & 58.5 & 22 & 13.4 & \\
\hline Yes, there is & 60 & 36.6 & 132 & 80.5 & \\
\hline $\begin{array}{l}\text { There is none, because no cancer can be } \\
\text { avoided }\end{array}$ & 4 & 2.4 & 7 & 4.3 & \\
\hline No answer & 4 & 2.4 & 3 & 1.8 & \\
\hline
\end{tabular}

Tests used: $\chi^{2}$ test (McNmear); ${ }^{*}$ Fisher's exact test.

Only $18.3 \%$ of interviewees reported having attended previous talks concerning sexual education, and the percentage rose to $54.9 \%$ in the questionnaire done afterwards, showing that they did not know what a sexual education talk really was about. Among the students who had already attended such lecture, 93.3\% reported that these talks were given at school.

\section{DISCUSSION}

The interest for studying adolescence today stems from the post-war demographic explosion, which had, as immediate consequence, the marked growth in the percentage of the young population in the world, as the expansion of the age range with characteristics of adolescents ${ }^{(18)}$. Educational programs for adolescents are important to prevent specific problems of this age group, and in order to be implemented, it is necessary to have proper knowledge about this group ${ }^{(19)}$.

Complying with prior publications, the present study observed that adolescents do not have much knowledge about STDs ${ }^{(9,20)}$. Among the STDs, AIDS was the disease which was most remembered by the interviewees, ratifying literature data pointing out that over $50 \%$ of teenagers know about the disease ${ }^{(20)}$. Taquette et al. ran a study with young women who went to the Núcleo de Estudos de Saúde do
Adolescente of Universidade Estadual do Rio de Janeiro (UERJ), where the women interviewed were afraid of being infected specifically by the AIDS virus and not any other type of disease ${ }^{(21)}$. Evidence from some studies reports that after the discovery of the immunodeficiency virus and the massive disclosure of its means of prevention in the press, people concerned with STDs were concerned with AIDS prevention ${ }^{(21,23)}$. We must also stress that the population in our study benefit from Health Educational Programs for STDs prevention, from the Municipal Secretariat of Health as well as from Faculdade de Medicina de Jundiaí.

Knowledge about condoms and the evidence that they prevent STDs was seen in the majority of the women that were interviewed in this study, and similar findings are reported in the literature ${ }^{(12,24)}$. Despite such knowledge, condoms are not regularly used ${ }^{(12)}$. Considering the risk of pregnancy as well, Belo et al. conducted a study with pregnant adolescents aged 19 years of age or younger and found that $54.5 \%$ of participants in this study reported having used some contraceptive method in their first intercourse, and the condom was the most mentioned method $(91.7 \%)$, followed by oral hormonal contraceptive and coitus interruptus. They also state that after educational lectures concerning STDs, the increased use of condoms was relevant ${ }^{(25)}$. Although the use of male condom is the predominant contraceptive method found in most studies, many of the interviewees are not aware of the proper way of using it and its efficacy ${ }^{(11)}$.

In the present study it is important to highlight the fact that when asked about which STDs they knew, only the minority mentioned HPV. However, at another point of the study, when questioned on their knowledge about the HPV, positive answers rose to more than half, since the following was asked: "Have you ever heard of the HPV?" and there were only three answer options: "Never heard of it", "I have heard of it but I do not know what it is", and "I have heard about and I know what it is". Knowledge does not lead to practice alone, showing that Health education must be followed by actions which make practice becomes reality ${ }^{(18)}$.

This study showed - like in previous studies - that many adolescents interviewed knew about the Pap smear test and considered it important, but they were not aware of its true function ${ }^{(26,27)}$. Nonetheless, inadequate or incomplete knowledge about the Pap smear test can bring about a negative behavior concerning doing the test and the frequency with which it must be performed. Brenna et al. investigated knowledge of women with uterine cervical cancer about the preventive Pap smear test and reported that $63 \%$ of the subjects had inadequate knowledge about it; most of them $(81 \%)$ had an inadequate behavior regarding the need to do it and $56 \%$ did it in an inadequate way ${ }^{(28)}$.

We can still stress the fact that when asked about the use of some uterine cervical cancer prevention 
method, most female adolescents said no, thus proving a confusion regarding the role of the Pap smear test. Different from literature reports, our study found that information about the test was provided more at home than in other places, such as schools ${ }^{(20,23)}$. This may be explained by the fact that the mothers of these adolescents are more concerned about uterine cervical cancer and about the health of their daughters ${ }^{(9)}$, thus stimulating them to go to the gynecologist earlier.

Many studies emphasize the need of cervical-vaginal cytology tests as a method to screen HPV-induced lesions and uterine cervical cancer ${ }^{(24,29,30)}$. Although most adolescents in the present study were aware of the need of collecting material for a Pap smear test after the first sexual intercourse, they were confused when asked about who should be submitted to such test. This is probably due to the fact that many adolescents do not know about the real need or function of the test.

\section{CONCLUSION}

We concluded that the level of knowledge about prevention of STDs and uterine cervical cancer among adolescents studied in the city of Jundiaí is low, and this is of much concern given the incidence and future implications of these diseases. We also concluded that educational lectures are inexpensive and represent a broadly encompassing action which could revert this situation of lack of knowledge of adolescents regarding STDs and uterine cervical cancer.

\section{REFERENCES}

1. Alves AS, Lopes MHBM. Conhecimento, atitude e prática do uso de pílula e preservativo entre adolescentes universitários. Rev Bras Enferm. 2008;61 (1):11-17.

2. Ramos C, May S. Aspectos históricos das doenças sexualmente transmissíveis. In: Secretaria Municipal de Saúde do Rio de Janeiro. Saúde em foco. Rio de Janeiro: Editora da Secretaria Municipal de Saúde do Rio de Janeiro; 1998. p. 5-11.

3. Taquette SR, Ruzany MH, Meirelles Z, Ricardo I. Relacionamento violento na adolescência e risco de DST/AIDS. Cad Saúde Pública. 2003;19(5):1437-44.

4. Silber TJ, D'Angelo L, Woodward K. El SIDA y otras enfermedades de transmissión sexual. In: Organización Panamericana de la Salud. La salud del Adolescente y del Joven; 1995. p. 273-84.

5. Doreto DT, Vieira EM. 0 conhecimento sobre doenças sexualmente transmissíveis entre adolescentes de baixa renda em Ribeirão Preto, São Paulo, Brasil. Cad Saúde Pública [Internet]. 2007 [citado 2009 Fev 4];23(10):2511-6. Disponívelem:http://www.scielo.br/scielo.php?script =sci_ arttext\&pid $=$ S0102-311X2007001000026\&lng $=$ pt\&nrm $=$ iso

6. Carret MLV, Fassa AG, Silveira DS, Bertoldi AD, Hallal PC. Sintomas de doenças sexualmente transmissíveis em adultos: prevalência e fatores de risco. Rev Saúde Pública. 2004;38(1):76-84.

7. Brasil. Ministério da Saúde. Dados e pesquisas em DST e Aids [Internet]. [citado 2007 Dez 2]. Disponível em: http://www2.datasus.gov.br/siscam/mapa4. php? saude $=. . /$ siscam $/$ mapa4.php\&botaook $=0$ K\&obj= ../siscam $/ \mathrm{mapa4}$.php

8. Brasil. Ministério da Saúde. Dados e pesquisas em DST e Aids [Internet]. [citado 2002 Nov 27]. Disponível em: http://www.aids.gov.br
9. Codes JS, Cohen DA, Melo NA, Santos AB, Codes JJG, Silva-Júnior JC, et al. Detecção de doenças sexualmente transmissíveis em clínica de planejamento familiar da rede pública no Brasil. Rev Bras Ginecol Obstet. 2002;24(2):101-6.

10. Simon CP, Silva RC, Paiva V. Prostituição juvenil feminina e a prevenção da Aids em Ribeirão Preto, SP. Rev Saúde Pública. 2002;36(4):82-7.

11. Gir E, Moriya TM, Hayashida M, Duarte G, Machado AA. Medidas preventivas contra a Aids e outras doenças sexualmente transmissíveis conhecidas por universitários da área de saúde. Rev Latino-Am Enfermagem. 1999;7(1):11-7.

12. Brasil. Ministério da Saúde. Instituto Nacional de Câncer. Incidência de câncer no Brasil: estimativa 2008 [Internet]. [citado 2007 Dez 2]. Disponível em : http:// www.inca.gov.br/estimativa/2008/index.asp?link $=$ conteudo_view.asp\&lD $=5$

13. Taquette SR, Andrade RB, Vilhena MM, Paula MC. A relação entre as características sociais e comportamentais da adolescente e as doenças sexualmente transmissíveis. Rev Assoc Med Bras. 2005;51(3):148-52.

14. Adih WK, Alexander CS. Determinants of condom use to prevent HIV infection among youth in Ghana. J Adolesc Health. 1999;24(1):63-72.

15. Murphy DA, Durako SJ, Moscicki AB, Vermund SH, Ma Y, Schwarz DF, Muenz LR; Adolescent Medicine HIV/AIDS Research. No change in health risk behaviors over time among HIV infected adolescents in care: role of psychological distress. J Adolesc Health. 2001;29(3 Suppl):57-63.

16. Borràs JM, Guillen $M$, Sánchez V, Juncà $S$, Vicente R. Educational level, voluntary private health insurance and opportunistic cancer screening among women in Catalonia (Spain). Eur J Cancer Prev. 1999;8(5):427-34.

17. Figueiredo R, Pupo LR, Segri NJ. Comportamento sexual e preventivo de adolescentes de São Paulo: um estudo com estudantes do ensino médio. Bol Instituto de Saúde. 2008;46(1):31-3.

18. Faustini DMT, Novo NF, Cury MCFS, Juliano Y. Programa de orientação desenvolvido com adolescentes em centro de saúde: conhecimentos adquiridos sobre os temas abordados por uma equipe multidisciplinar. Ciênc Saúde Coletiva. 2003;3(8):783-90.

19. Jeolás LS, Ferrari RAP. Oficinas de prevenção em um serviço de saúde para adolescentes: espaço de reflexão e de conhecimento compartilhado. Ciênc e Saúde Coletiva. 2003;8(2):611-20.

20. Fernandez AMS. Conhecimento, atitudes e práticas de mulheres brasileiras atendidas pela rede básica de saúde com relação às doenças de transmissão sexual. Cad Saúde Pública. 2000:16(supl. 1):103-12.

21. Taquette SR, Ruzany MH, Meirelles Z, Ricardo I. Relacionamento violento na adolescência e risco de DST/AIDS. Cad Saúde Pública. 2003;19(5):1437-44.

22. Leite MTF, Costa AVS, Carvalho KAC, Melo RLR, Nunes BMTV, Nogueira LT. Saber e prática contraceptiva e prevenção de DST/HIV/AIDS em universitários da área de saúde. Rev Bras Enferm. 2007;60(4):434-8.

23. Queiroz DT, Pessoa SMF, Sousa RA. Infecção pelo Papiloma Vírus Humano (HPV): incertezas e desafios. Acta Paul Enferm. 2005:18(2):190-6.

24. Ruzany MH, Taquette SR, Oliveira RG, Meirelles ZV, Ricardo IB. A violência nas relações afetivas dificulta a prevenção de DST/AIDS? J Peditria (Rio J). 2003;79(4):349-54.

25. BeloMAV, Silva JLP.Conhecimento, atitude prática sobre métodos anticoncepcionais entre adolescentes gestantes. Rev Saúde Pública. 2004; 38(4):479-87.

26. Lopes ER, Rebelo MS, Abreu E, Silva VLC, Eisenberg ALA, Lavor MF. Comportamento da população brasileira feminina em relação ao câncer cérvico-uterino. J Bras Ginecol. 1995;105(11/12):505-15.

27. Gamarra CJ, Paz EPA, Griep RH. Conhecimentos, atitudes e prática do exame de Papanicolaou entre mulheres argentinas. Rev Saúde Pública. 2005;39(2):270-6.

28. Brenna SMF, Hardy E, Zeferino LC, Namura I. Conhecimento, atitude e prática do exame de Papanicolau em mulheres com câncer de colo uterino. Cad Saúde Pública. 2001;17(4):909-14.

29. Workowski KA, Berman SM. CDC sexually transmitted diseases treatment guidelines. Clin Infect Dis. 2002;35(Suppl 2):S135-7.

30. Sebastião APM, Noronha L, Carvalho NS, Collaço LM, Bleggi-Torres LF. Estudo das atipias indeterminadas em relação à prevalência e ao percentual de discordância nos casos do Programa de Prevenção do Câncer Uterino do Paraná. J Bras Patol Med Lab. 2004;40(6):431-8. 
Appendix 1. Questionnaire

Record number: I___ا__

1. Age: I_l_l years

2. Current school grade:
a. $6^{\text {th }}$ grade (Junior School)
b. $7^{\text {th }}$ grade (Junior School)
C. $8^{\text {th }}$ grade (Junior School)
d. $9^{\text {th }}$ grade (Junior School)
e. $10^{\text {th }}$ grade (High School)
f. $11^{\text {th }}$ grade (High School)
g. $12^{\text {th }}$ grade (High School)

\section{School:}
a. EMEB Maria José Maia de Toledo
b. EMEB Rotary Club
c. EMEB Dep. Ranieri Mazzilli
d. EE Cel. Siqueira de Moraes
e. EE Bispo Dom Gabriel P. B. Couto
f. EMEB Prof. Albino Melo de Oliveira
g. EMEB Morada das Vinhas
h. EMEB Prof. Luiz Rivelli
i. EE Padre Maurilio Tomanik

4. Do you have or already had sexual education class?
a. Yes
b. No

\section{Do you know what a sexually transmitted} disease is?
a. Yes
b. No

6. Write down the sexually transmitted diseases you know:

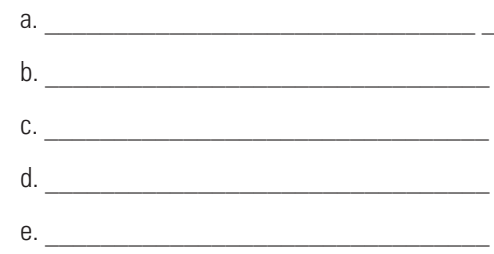

7. Do you think it is important to use condoms?
a. I do not think so
b. I do not know
c. Yes, if the woman does not take the pill, the couple should use condom to avoid getting pregnant
d. Yes always, because it avoids pregnancy and prevents diseases

\section{Do you think women should make appointments with gynecologists?}

a. I do not know
b. I do not think so
c. Yes, only if they have any problem
d. Yes, at least once a year

\section{Have you heard about HPV?}

a. I have never heard

b. I have heard, but I do not know exactly what it is

c. I have heard, and I know what it is:

10. Have you heard about Pap smear test?
a. I have never heard
b. I have heard: $\square$ at school $\square$ on television
$\square$ in newspaper $\square$ in lectures $\square$ at home
$\square$ by friends $\square$ other places:

\section{What is the Pap smear test for?}
a. I do not know
b. To avoid diseases
c. To avoid uterine cervical cancer
d. To avoid any cancer in women

12. Do you think it is necessary to undergo this test?
a. I do not know
b. I think it is not necessary
c. I think it is not very necessary
d. I think it is very necessary

13. Who should undergo this test?
a. Women with active sexual life
b. Women after menarche (first menses)
c. Woman aged over 5 years

14. Do you know someone who had cervical cancer?
a. I have never heard
b. I have heard: $\square$ at school $\square$ on television
$\square$ in newspaper $\square$ in lectures $\square$ at home
$\square$ by friends $\square$ other places:

15. Do you know if there is any test to prevent cervical cancer?
a. I do not know
b. Yes, there is
c. There is none, because no cancer can be avoided

16. Do you know someone who had breast cancer?

a. I have never heard

b. I have heard: $\square$ at school $\square$ on television $\square$ in newspaper $\square$ in lectures $\square$ at home $\square$ by friends $\square$ other places:
17. Have you heard about breast selfexamination?
a. I have never heard
b. I have heard: $\square$ at school $\square$ on television
$\square$ in newspaper $\square$ in lectures $\square$ at home
$\square$ by friends $\square$ other places:

18. How should breast self-examination be performed? (explain briefly)

a.

b.

c.

d.

e.

19. Do you think is important for women to examine their breasts?
a. Yes
b. No

20. Have you heard about mammography?
a. I have never heard
b. I have heard: $\square$ at school $\square$ on television $\square$ in newspaper $\square$ in lectures $\square$ at home
$\square$ by friends $\square$ other places:

\section{Who should undergo mammography?}

22. Where can mammography be performed?
a. Hospital
b. Office
c. Primary healthcare clinic
d. At all places mentioned above

23. Have you ever undergone mammography?
a. No
b. Yes. How many?

\section{$\square$ Once \\ $\square$ Twice \\ $\square$ More}

\section{Have you ever participated in such a} lecture? Where?

25. What is your opinion about the lecture?
a. Poor
b. Regular
c. Good
d. Excellent 